Pure Appl. Bio., 1(3): 52-58, Dec- 2012.

Review Article

\title{
AN INSIGHT OF COTTON LEAF CURL VIRUS: A DEVASTATING PLANT PATHOGENIC BEGOMOVIRUS
}

\author{
Mahmood-ur-Rahman ${ }^{* a}$, Khadim Hussain ${ }^{\mathrm{a}}$, Muhammad Azmatullah Khan ${ }^{\mathrm{b}}$, Allah Bakhsh ${ }^{\mathrm{c}}$ and Abdul Qayyum Rao ${ }^{\mathrm{b}}$ \\ a Plant Research Group, Department of Bioinformatics and Biotechnology, Government College University, Faisalabad, Pakistan. \\ ${ }^{\mathrm{b}}$ National Centre of Excellence in Molecular Biology (CEMB), University of the Punjab, Lahore, Pakistan. \\ ${ }^{\mathrm{C}}$ Department of Field Crops, Faculty of Agriculture, Ankara, Turkey. \\ *Corresponding author: mahmood1233@yahoo.com (+92-301-3967919)
}

\begin{abstract}
Genome of plant viruses consists of either RNA or DNA. DNA viruses can be categorized into two types, (1) circular double-stranded DNA (dsDNA), these viruses are able to replicate through the process of reverse transcription from RNA (the caulimoviruses and badnaviruses), (2) viruses that have circular single-stranded DNA (ssDNA), which replicate through a dsDNA intermediate (the Geminivirus and nanoviruses). Begomoviruses are whiteflies transmitted geminiviruses and infect many economically important dicotyledonous crops including cotton, potato, tomato, cassava and chili. Begomoviruses cause leaf curl disease in cotton. In this review article, the Cotton Leaf Curl Virus (CLCuV) has been introduced systematically.
\end{abstract}

Keywords: Begomovirus, Cotton Leaf Curl Disease, Gossypium hirsutum L., Resistance management, White fly

\section{Introduction}

Cotton is a cultivated crop in about 70 countries worldwide [1]. Over 180 million people are directly or indirectly associated with the fibre industry [1]. Cotton is a member of the genus Gossypium of the family Malvaceae. The cultivated species are organized in two sections, Herbacea and Hirsuta. Section Herbacea includes two species, $G$. herbaceum L. and G. arboreum L. Both are diploids, each having a number of cultivars. The vast majority of cotton produced throughout the world is derived from cultivars of two new world species in the section Hirsuta, i.e. G. hirsutum and G. barbadense. Both the new world species are allopolyploids derived from hybridization between two diploid species. G. hirsutum varieties are grown in numerous countries scattered over five continents [2].

Cotton has the unfortunate characteristics of being vulnerable to many insects, and to maintain yield, insects are managed with large amounts of insecticides. For the first time, cotton leaf curl disease $(\mathrm{CLCuD})$ was observed in severe forms at the seedling stage on cotton verities imported from US $[3,4]$. The incidence of the disease was as high as $80 \%$ in these varieties [5]. By early 1990's, CLCuD had become the major malady, which gave serious setback to cotton production in Pakistan [4,6]. The damage to cotton crop ( $G$. Hirsutum) done by the CLCuD has been studied in Nigeria, Sudan and Tanzania where the disease caused a reduction in the number of bolls by 87.4 and $38.8 \%$ in boll weight and $92.2 \%$ in seed cotton yield $[7,8]$.

The begomoviruses are responsible for CLCuD. The disease is caused by the association of beta satellite (previously known as DNA $\beta$ ) which is unique ssDNA satellite [9]. The characteristic symptoms of the disease are: curling of the leaves, dark and swollen veins, and enations on the undersides of leaves which are developed into leaf like structures $[10,11]$. Whitefly (Bemisia tabaci Gann.) is carrier which is responsible for the disease epidemic of CLCuV.

\section{Family Geminivirideae}

The Geminiviridae family has several members which infect plants and results in reduced yield of economically important crops [12]. All the members have some common features including the geminate morphology of the virion particle and the nature of their genetic material. The Geminiviruses gnomes have bidirectional promoted and highly conserved nonanucleotied sequence (TAATATTAC) which is part of the origin of replication of the virion strand. This sequence is very important due to presence of initiation site for rolling circle replication $(\mathrm{RCR})$ in it $[13,14,15]$.

When the Geminivirus protein accumulates in plant, they cause interruption in various plant pathways [16] which include: (1) the changes in the structure and functions of plasmodesmata [17] that may be associated with host cell defense mechanisms $[18,19,20]$, (2) the interaction among different proteins involved in regulating development [21], (3) hyperplasia $[22,23]$, (4) up or down regulation in gene expression [24] and (5) the interference with the retinoblastoma related pathway $[25,26]$.

Geminiviridae family consists of four genera. The family members of Geminiviridae are categorized on the basis of genome organization, host range and insect vectors. The insect vectors are whiteflies (genus Begomovirus), leafhoppers (genera Mastrevirus and Curtovirus) and treehoppers (genus Topocuvirus) [27]. 


\section{Curtoviruses}

Curtoviruses consist of monopartite genome and infect dicotyledonous plants. They encode V2 and V1 (coat protein) on the virion - sense strand. On the complementary-sense strand, there are four open reading frames (ORFs): Rep, C2, REn and C4 [25]. The representative member is Beet curly top virus (BCTV) (Figure-1).

\section{Topocuviruses}

Topocuvirus is the less characterized genus of family Geminivirus and contain single species identified. They also contain a monopartite genome. Their genome organization is very much identical to curtoviruses. Tomato pseudo-curly top virus (TPCTV) is an example of topocuviruses genus (Figure-1).

\section{Mastreviruses}

It has a monopartite genome and principally infects the monocotyledonous species but some viruses of this genus may also infect the dicotyledonous plants e.g., tobacco and bean yellow dwarf virus (TYDV \& BYDV). Moreover, they have two important characteristics: (1) there are two intergenic regions small intergenic region (SIR) and large intergenic region (LIR) and presence of 80 nucleotide long DNA sequence with a region in the SIR, and (2) the occurrence of a splicing event on the c-sense transcript of the Rep gene [28]. The examples of these viruses are Maize streak virus (MSV), Wheat dwarf virus (WDV) and Digitaria streak virus (DSV) (Figure-1).

\section{Begomoviruses}

Most of the begomoviruses in the New World have two components, DNA A and DNA B is known as bipartite begomoviruses. The presence of both the components is necessary for virus integrity and disease development. There are some common regions of two genomic components of bipartite begomoviruses that have motifs essential for regulation of gene expression and replication [29]. Theses motifs include conserved motifs and stem loop structure having the TAATATTAC sequence [29]. This conserved sequence is required at the initiation of replication [29].

In Old World, most begomoviruses such as Tomato yellow leaf curl virus (TYLCV) [30], which have only one genomic component DNA A termed as monopartite begomoviruses. However, this is not the case for all monopartite Begomoviruses such as Ageratum yellow vein virus (AYVV) and Cotton leaf curl Multan virus (CLCuMV) [28]. CLCuMV has been a major cause of disease epidemics in Pakistan which reduced the cotton production significantly $[10,31]$. The AYVV and CLCuMV caused infection
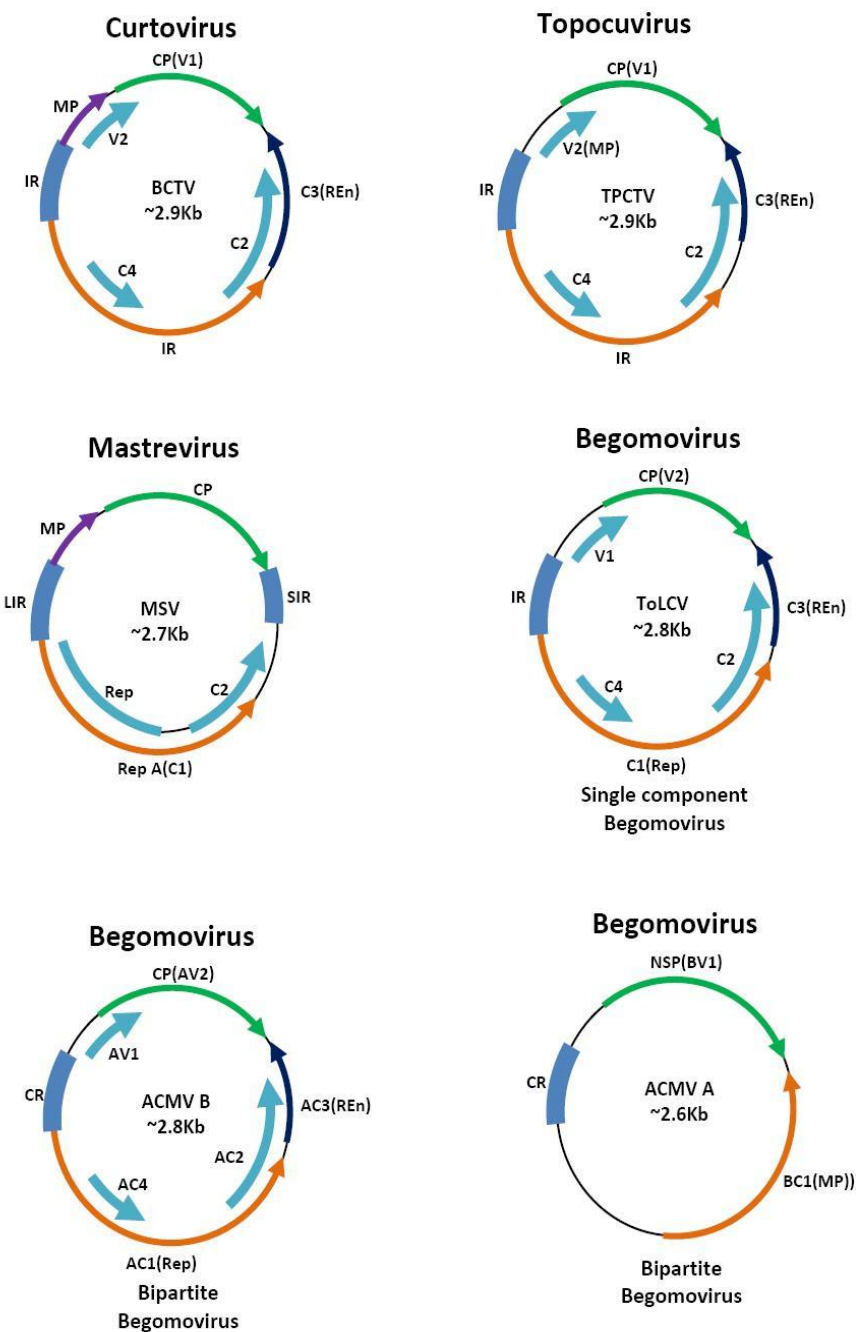

Figure-1. The genome organisation of representative members of the four Geminivirus genera. (i) MSV; Maize streak virus, (ii) BCTV; Beet curly top virus, (iii) TPCTV; Tomato pseudo-curly top virus, (iv) ACMV; African cassava mosaic virus, (a) ACMV A, (b) ACMV B, (c) ToLCV; Tomato leaf curl virus. C: Curved arrows indicate open reading frames, diverging in the complementary, $\mathrm{V}$ : the virion, IR: an intergenic region, LIR: a long intergenic region, CR: a common region, MP: movement protein, CP: coat protein, TrAP: transcription activator protein, REn: replication enhancer protein, NSP: nuclear shuttle protein. The plus strand rolling circle replication initiation site (TAATATTAC) is situated within the loop of a stem-loop structure which is indicated within each genus. The bidirectional transcription initiates in the long intergenic region and terminates in the short intergenic region (SIR), which contains signals for polyadenylation in mastreviruses.

in ageratum and cotton, respectively but the viral load was too low to produce typical disease symptoms in ageratum and cotton concluding that an additional component might be essential for disease causing and beta satellite (previously known as DNA $\beta$ ) was found to be important in symptom production [32]. 
Dry et al., [33] isolated ssDNA component from tomato infected with tomato leaf curl virus (ToLCV), a begomovirus. It was the first time when a satellite DNA was discovered associated with DNA viruses. This component is associated with ToLCV and in combination, it is responsible for systemic movement, replication and insect transmission. It has a stem loop sequence which contains the conserved TAATATTAC sequence, a typical Geminivirus but no extended open reading frames [34]. Another major advance occurred when ssDNA component of approximately half the size of the Begomovirus component (1376 nucleotides) was isolated from cotton infected with CLCuMV [34]. The similar results were obtained in association with AYVV in infected ageratum [35]. So, it was suggested that the monopartite viruses are the ancestors of bipartite viruses and the bipartite begomoviruses might have evolved from a monopartite virus by component duplication (Figure-1).

\section{Cotton leaf curl disease (CLCuD) History}

Cotton Leaf Curl Disease, a viral disease of cotton, was first reported in 1912 from Nigeria [36]. Later on it was reported from Tanzania in 1926 [37] and from Sudan in 1934. In Pakistan, Cotton Leaf Curl Disease (CLCuD) was first time noticed near Multan in 1967 [38]. Due attention was not paid to the disease at the beginning because of its un-noticed economic loss to the crop. Since 1987 it has become a major threat to the cotton crop of Pakistan [39].

Mubin et al., [40] reported the nucleotide sequences and phylogenetic analyses of the Begomovirus disease complex in association with yellow vein disease of Digera arvensis. It has $98 \%$ sequence identity with Cotton leaf curl Rajasthan virus (CLCuRV). They also identified two betasatellite species in $D$. arvensis. This discovery indicates that weeds can be important sources of multiple Begomovirus components that affect crop plants and suggested that weeds are likely vessels for recombination and evolution of components of Begomovirus complexes.

Etiology

Although the most attention is attracted by Cotton Leaf Curl Disease (CLCuD) from the late 1980 s to the early 1990 s, various other crops and weeds (tomato, pepper, cucurbits, legumes, ageratum, croton, Eclipta prostrate, croton and nightshade) also showed the symptoms very similar to those caused by viruses [41,42,43,44].

\section{A Begomovirus associated with cotton leaf curl} disease

The Begomovirus genus has more than 70 members which are transmitted by the whitefly (Bemisia tabaci). The whitefly infects only dicotyledonous plants. Cassava mosaic virus (CMV), a representative member of begomovirus is the most dangerous virus responsible for the low yield in South and Central Africa $[45,46]$. Another example is a tomato yellow leaf curl viruses (TYLCVs), which is a serious problem with tomato across the Mediterranean region [47,48], Caribbean [49], Florida [50]. The finding that whitefly (B. tabaci) transmits specifically CLCuD led researchers to conclude that a Begomovirus might cause the disease. The associated Begomovirus with CLCuD was named Cotton leaf curl virus (CLCuV).

DNA components required for induction of cotton leaf curl disease

The genomes of the majority of Begomoviruses consist mainly of two ssDNA molecules, DNA A and DNA B [51,52]. The DNA A encodes viral functions required for replication [53], regulation of gene expression as well as the coat protein, which is important in insect transmission [54]. The component DNA B encodes two proteins involved in virus movement within plants $[53,55]$ and for the bipartite begomoviruses, their products are symptom determinants $[56,57]$. All the viral products required for replication, gene expression, whitefly transmission, and systemic infection are encoded in DNA A [30,58]. The products responsible for cellular movements within and between cells are encoded by DNA B [55]. Genomes of some begomoviruses consist of just a single component, equivalent to DNA A of the bipartite viruses which performs all the functions of replication, transcription regulation, encapsidation and movement.

Symptoms of CLCuD

The most characteristic symptoms of this disease include leaf curling, vein swelling, vein darkening, and enations on the veins on the underside of leaves, which are frequently developed into leaflike structures [10]. Infected plant has stunted young leaves and shoots. The growth is very slow, becomes bushy, and dwarfed. The leaf margin rolls either inward or upward and they are stiff with yellowish margin. The leaves are thicker than normal, with a leathery texture. The young leaves have a yellowish color, cupped, thick, and rubbery (Figure-2).

Inheritance of $\mathrm{CLCuV}$ resistance

Ali [59-60] was of the opinion that the $\mathrm{CLCuV}$ resistance is controlled by a single dominant gene and can be transferred to any cultivar by using back cross technique. According to Knight [61], a single mass selection in a moderately resistant population was reported to have produced a highly resistant type. According to Tarr [62], the virus resistance may not always be a stable quality. It was suggested by Hutchinson and Knight [63] that the breeding of resistant types has been accomplished by 
the accumulation of minor genes by repeated selection. Later, Siddig [64] found that the resistance may be due to a single dominant gene.

Wilson and Brown [65] studied the inheritance of $\mathrm{CLCuV}$ infection in cotton. The results indicated that factors controlling symptoms/expression were inherited as duplicate factors and that the susceptible phenotype (genotype $\mathrm{c} 1 \mathrm{c} 1 \mathrm{c} 2 \mathrm{c} 2$ ) was recessive to the phenotype i.e., resistant phenotype (genotype c1- c2), which mean that at least one dominant gene must be present in a genotype for resistance to CLCuV.

Ali [59] studied the inheritance of $\mathrm{CLCuV}$ resistance in upland cotton and reported that resistance was monogenic and dominant in nature. Mansoor et al., [34] reported that cotton genotypes, susceptible to $\mathrm{CLCuV}$ accumulated several fold higher level of viral DNA as compared to the tolerant varieties.

\section{Resistance management strategy}

The easiest and cheapest method of controlling plant disease is the development of resistant variety $[66,67]$ and good management practices $[68,69]$ and they are the only permanent solution to the problem [70]. During the last several years, considerable efforts have been made by different research organizations to develop CLCuV resistant cultivars. For a successful breeding program, a reliable screening technique is necessary to identify genetic resources [70,71]. CLCuV could be managed by growing arboreum cotton in disease affected areas. The resistance is controlled by a single gene and can be transferred to any cultivar by a back-cross technique [72].

Most of the cotton materials are susceptible to $\mathrm{CLCuV}$ infection. However, their level of susceptibility varies $[71,72,73]$. Some genotypes are easily infected while others are harder to infect and has slow disease development, especially those materials developed through radiation. The problem should not be considered solved, because four variants of $\mathrm{CLCuV}$ have been shown to exist in the field [44]. Multiple infection of $\mathrm{CLCuV}$ and other whitefly-transmitted Geminiviruses (WTGs) in cotton and other cotton growing areas are prevalent, therefore, chances of recombination among them and other WTGs do exist, which may lead to the emergence of new, more virulent and resistant breaking variants [74]. The results of this study suggest that preference should be given to those plants that exhibited highly resistant responses after artificial inoculation. Meanwhile, the search for immune materials (through artificial inoculation) should continue.
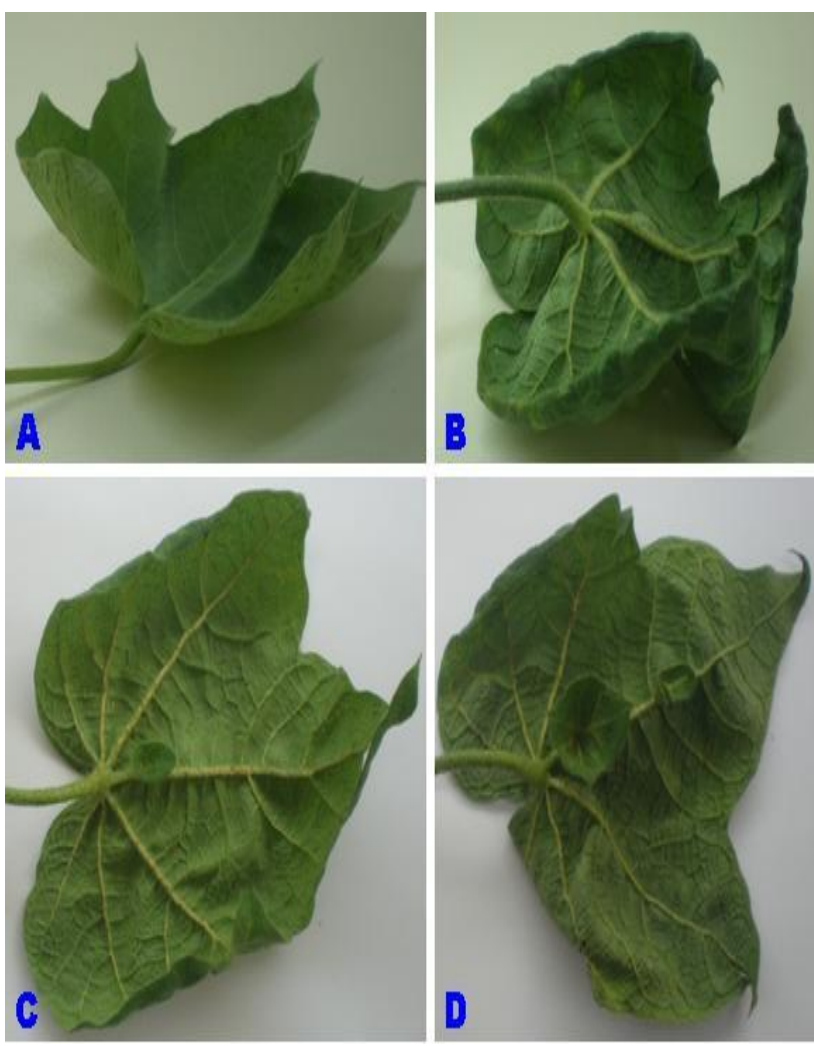

Figure-2: Typical symptoms of cotton leaf curl disease in cotton. The leaf margin rolls either inward or upward and they are stiff with yellowish margin (A \& B). The disease causes vein swelling and enations on the veins on the undersides of leaves, which frequently develop into large leaf-like outgrowths (C \& D). Back-lighting shows the characteristic vein darkening symptoms.

Prevention and control measures

1. Use only resistant cultivars which can tolerate the disease

2. The seedlings should be protected from whiteflies

3. Use only good quality seeds and healthy transplants

4. The whiteflies should be controlled

5. Infected plants should immediately be removed and disposed of

6. Control weeds

7. Do not grow cotton near tomato and/or other crops susceptible to begomoviruses.

8. Practice crop rotation by planting crops that are not host of begomoviruses.

\section{Acknowledgements}

The authors gratefully acknowledge the financial support from Higher Education Commission, Government of Pakistan for the completion of this research work

\section{Reference}

1. Anonymous (1996). Minutes of the second meeting on scoring Cotton leaf curl virus disease, p. 3. 
Jointly organized by (i) Ayub Agriculture Research Institute, Faisalabad-Pakistan, (ii) Department of Plant Pathology, University of Agriculture Faisalabad-Pakistan, and (iii) Ministry Food Agriculture and Livestock, Government of Pakistan, Islamabad.

2. Afzal M, Ali M (1983). History of Cotton: Cotton Plant in Pakistan, pp. 1-9. Aiwan-e-Science, Shahrah-e-Romi , Lahore

3. Rashida P, Sultan MK, Khan MA, Islam N (2005). Screening of cotton germplasm against cotton leaf curl Begomovirus (CLCuV). Journal of Agricultural and Social Sciences 1(3):235-238.

4. Akhtar KP, Haider S, Khan MKR, Ahmad M, Sarwar N, Murtaza MA, Aslam M (2010). Evaluation of Gossypium species for resistance to leaf curl Burewala virus. Annals of Applied Biology 157:135-147

5. Ali M, Ahmad Z, Tanveer M, Mahmood T (1995). Identification and characterization of virus in: "Cotton leaf curl virus in the Punjab during 199192". CLCuV Project, Asian Development Bank, Ministry of Food, Agriculture and Livestock, Government of Pakistan.

6. Akhtar KP, Wasim M, Ishaq W, Ahmed M, Haq MA (2009). Deterioration of cotton fiber characteristics caused by cotton leaf curl disease. Spanish Journal of Agricultural Research 7(4):913-918.

7. Singh JA, Sohi S, Brar DS, Denhdm I, Russel D, Briddon R (1999). Management of cotton leaf curl virus disease in India. Proc. ICAC Regional Consultation Insecticide Resistance management in cotton. CCRI, Multan, Pakistan, pp. 277-284.

8. Monga D, Chakrabarty PK, Kranthi R (2011). Cotton leaf Curl Disease in India-recent status and management strategies. Presented in 5th meeting of Asian Cotton Research and Development Network Held in Lahore in Feb 23-25, 2011.

9. Mansoor S, Briddon RW, Bull SE, Bedford ID, Bashir A, Hussain M, Saeed M, Zafar Y, Malik, KA, Fauquet C, Markham PG (2003). Leaf curl disease is associated with multiple monopartite Begomoviruses supported by single DNA b. Archives of Virology 148:1969-1986.

10. Briddon RW, Markham PG (2001). Cotton leaf curl disease. Virus Research 71:151-159.

11. Ahuja SL, Monga D, Dhyal LS (2007). Genetics of resistance to cotton leaf curl disease in Gossypium hirsutum L. under field conditions. Journal of Heredity 98(1):79-83.

12. Moffat AS (1999). Geminivirus emerge as serious crop threat. Science 286:1835.
13. Stanley J (1990). Defective viral DNA ameliorates symptoms of Geminiviruses infection in transgenic plants. Proceedings of National Academy of Sciences USA 87:6291-6295.

14. Stenger DC, Revington GN, Stevenson MC, Bisaro DM (1991). Replicational release of Geminiviruses genomes from tandemly repeated copies: evidence for rolling-circle replication of a plant viral DNA. Proceedings of National Academy of Sciences USA 88:8029-8033.

15. Heyraud F, Matzeit V, Kammann M, Schaefer S, Schell J, Gronenborn B (1993). Identification of the initiation sequence for viral-strand DNA synthesis of wheat dwarf virus. EMBO Journal 12:4445-4452.

16. Gutierrez C (2000). DNA replication and cell cycle in plants: learning from Geminivirus. EMBO Journal 19:792-799.

17. Lazarowitz SG (1999). Probing plant cell structure with viral movement proteins. Current Opinion in Plant Biology 2:332-338.

18. Peele C, Jordan CV, Muangsan N, Turnage M, Egelkrout E, Eagle P, Hanley-Bowdoin, Robertson D (2001). Silencing of a meristematic gene using Geminiviruses-derived vectors. Plant Journal 27:357-366.

19. Covey SN, Al-Kaff NS (2000). Plant DNA viruses and gene silencing. Plant Molecular Biology 43:307-322.

20. Voinnet O, Pinto YM, Baulcombe DC (1999). Suppression of gene silencing: a general strategy used by diverse DNA and RNA viruses of plants. Proceedings of National Academy of Sciences USA 96:14147-14152.

21.Xie Q, Sanz-Burgos AP, Guo H, García JA, Gutierrez C (1999). GRAB proteins, novel members of the NAC domain family, isolated by their interaction with a Geminiviruses protein. Plant Molecular Biology 39:647-656.

22. Stanley J, Latham JR (1992). A symptom variant of beet curly top Geminiviruses produced by mutation of open reading frame C4. Virology 190:506-509.

23. Latham JR, Saunders K, Pinner MS, Stanley J (1997). Induction of plant cell division by beet curly top virus gene C4. Plant Journal 11:1273-1283.

24. Nagar S, Pedersen TJ, Carrick KM, HanleyBowdoin L (1995). A Geminiviruses induces expression of a host DNA synthesis protein in terminally differentiated plant cells. Plant Cell 7:705-719.

25.Xie Q, Suarez-Lopez P, Gutierrez C (1995). Identification and analysis of a retinoblastoma binding motif in the replication protein of a plant 
DNA virus: requirement for efficient viral DNA replication. EMBO Journal 14:4073-4082.

26. Kong LJ, Orozco BM, Roe JL, Nagar S, Ou S, Feiler HS, Durfee T, Miller AB, Gruissem W, Robertson D, Hanley-Bowdoin L (2000). A Geminiviruses replication protein interacts with retinoblastoma through a novel domain to determine symptoms and tissue specificity of infection in plants. EMBO Journal 19:3485-3495.

27. Fauquet CM (2003). Revision of taxonomic criteria for species demarcation in the Geminiviridae family, and a new updated list of Begomovirus species. Archives of Virology 148:405-421

28. Briddon RW, Mansoor S, Bedford ID, Pinner MS, Markham PG (2000). Clones of cotton leaf curl Geminiviruses induce symptoms atypical of cotton leaf curl disease. Virus Genes 20:17-24.

29. Hanley-Bowdoin L, Settlage SB, Orozco BM, Nagar S, Robertson D (1999). Geminiruses: Models for plant DNA replication, transcription, and cell cycle regulation. Critical Reviews in Plant Sciences 18:71106.

30. Navot N, Pichersky E, Zeidan M, Zamir D, Czosnek H (1991). Tomato yellow leaf curl virus: a whiteflytransmitted Geminiviruses with a single genomic component. Virology 185:151-161.

31. Farooq A, Farooq J, Mahmood A, Shakeel A, Rehman A, Batool A, Riaz M, Shahid MTH, Mehboob S (2011). An overview of cotton leaf curl virus disease (CLCuD) a serious threat to cotton productivity. AJCS 5(13):1823-1831.

32. Ingham DJ, Pascal E, Lazarowitz SG (1995). Both bipartite Geminiviruses movement proteins define viral host range, but only BL1 determines viral pathogenicity. Virology 207:191-204.

33. Dry IB, Krake LR, Rigden JE, Rezaian MA (1997). A novel subviral agent associated with a Geminiviruses: the first report of a DNA satellite. Proceedings of National Academy of Sciences USA 94:7088-7093.

34. Mansoor S, Khan SH, Bashir A, Saeed M, Zafar Y, Malik KA, Briddon RW, Stanley J, Markham PG (1999). Identification of a novel circular singlestranded DNA associated with cotton leaf curl disease in Pakistan. Virology 254:290-299.

35. Saunders K, Bedford ID, Stanley J (2002). Adaptation from whitefly to leafhopper transmission of an autonomously-replicating nanovirus-like DNA component associated with ageratum yellow vein disease. Journal of General Virology 83:909-915.

36. Ferquharson CO (1912). A report of the Mycologist, Agri. Dept., Nigeria.
37. Jones GH, Mason TG (1926). Studies on two obscure diseases of cotton. Annals of Botany 160:722.

38. Hussain T, Ali M (1975). Pakistan Cottons 19 :71.

39. Hussain T, Mahmood T (1988). Pakistan Cottons 32 $: 248$.

40. Mubin M, Briddon RW, Mansoor S (2009). Diverse and recombinant DNA betasatellites are associated with a begomovirus disease complex of Digera arvensis, a weed host. Virus Research 142:208-212.

41. Haider MH (1996). Characterisation of whiteflytransmitted Geminivirus from Pakistan. Ph.D. Thesis. University of London, UK.

42. Harrison BD, Liu YL, Khalid S, Hameed S, OtimNape GW, Robinson DJ (1997). Detection and relationships of cotton leaf curl virus and allied whitefly-transmitted Geminivirus occurring in Pakistan Annals of Applied Biology 130:61-75.

43. Mansoor S, Khan SH, Saeed M (1997). Evidence for the association of a bipartite Geminiviruses with tomato leaf curl disease in Pakistan. Plant Disease 81:958.

44.Zhou X, Liu Y, Robinson DJ, Harrison BD (1998). Four variants among Pakistani isolates of cotton leaf curl virus and their affinities to DNA-A of Geminiviruses isolates from okra. Journal of General Virology 79:915-923.

45. Thottappilly G (1992). Plant virus diseases of importance to African agriculture. Journal of Phytopathology 134:265-288.

46. Legg JP, Thresh JM (2000). Cassava mosaic virus disease in East Africa: a dynamic disease in a changing environment. Virus Research 71:135-149.

47. Czosnek H, Laterrot H (1997). A worldwide survey of tomato yellow leaf curl viruses. Archives of Virology 142:1391-1406.

48. Moriones E, Navas-Castillo J (2000). Tomato yellow leaf curl virus, an emerging virus complex causing epidemics worldwide. Virus Research 71(1-2):12334.

49. McGlashan D, Polston JE, Bois D (1994). Tomato yellow leaf curl virus in Jamaica. Plant Disease 78:1219.

50. Polston JE, McGovern RJ, Brown LG (1999). Introduction of tomato yellow leaf curl virus in Florida and implications for the spread of this and other Geminivirus of tomato. Plant Disease 83:984988.

51. Stanley J, Gay MG (1983) Nucleotide sequence of cassava latent virus DNA. Nature 301:260-262. 
52. Rybicki EP (1994). A phylogenetic and evolutionary justification for three genera of Geminiviridae. Archives of Virology 139:49-77.

53. Stanley J (1983). Infectivity of the cloned Geminiviruses genome requires sequences from both DNAs. Nature 305:643-645.

54. Azzam O, Frazer J, de la Rosa D, Beaver JS, Ahlquist P, Maxwell DP (1994). Whitefly transmission and efficient ssDNA accumulation of bean golden mosaic Geminiviruses requires functional coat protein. Virology 204:289-296.

55. Noueiry AO, Lucas WJ, Gilbertson RL (1994). Two proteins of a plant DNA virus coordinate nuclear and plasmodesmal transport. Cell 76:925-932.

56. Klinkenberg FA, Stanley J (1990). Encapsidation and spread of African cassava mosaic virus DNA A in the absence of DNA B when agroinoculated to Nicotiana benthamiana. Journal of General Virology 71:1409-1412.

57. Arnim AV, Stanley J (1992). Determinants of tomato golden mosaic virus symptom development located on DNA B. Virology 186:286-293.

58. Rojas MR, Jiang H, Salati R, Xoconostle-Cazares B, Sudarshana MR, Lucas WJ, Gilbertson RL (2001). Functional analysis of proteins involved in movement of the monopartite Begomovirus, Tomato yellow leaf curl virus. Virology 291:110-125.

59. Ali M (1997). Breeding of cotton varieties for resistance to cotton leaf curl Virus. Pakistan Journal of Phytopathology 9(1):1-7.

60. Ali M (1999). Inheritance of cotton leaf curl virus $(\mathrm{CLCuV})$, Proceedings of ICAC-CCRI Regional Consultation Insecticide Resistance Management in Cotton, June 28-July 01, Multan, Pakistan, 257-260.

61. Knight RL (1954). Cotton breeding in the Sudan. Emperical Journal of Experimental Agrico 85:68-80

62. Tarr SAJ (1951). Leaf curl diseases of cotton. Common W. Mycol. Internat., Kew, Surrey.

63. Hutchinson JB, Knight RL (1950). Response of cotton to leaf curl disease. Journal of Genetics 50:100-111.

64. Siddig MA (1968) Genetics of resistance to cotton leaf curl in Sakel Cotton. Journal of Agricultural Science 70:99-103.

65. Wilson FD, Brown JK (1991). Inheritance of response to cotton leaf crumple virus infection in cotton. Journal of Heredity 82:508-509.

66. Agrios GN (1978). Plant pathology Deptt. of plant Pathology Univ. of Florida 2nd ed. A. P. London, pp: 703.

67. Akhtar KP, Hussain M, Khan AI, Khan MSI (2000). Screening of cotton mutants for the resistance against Cotton leaf curl virus (CLCuV). Pakistan Journal of Biological Sciences 3(1):91-94.

68. Iqbal M, Khan MA (2010). Management of Cotton leaf curl virus by planting time and plant spacing. Advances in Agriculture and Botanics (2)1:25-33.

69.Zafar UZ, Athar HUR, Ashraf M (2010). Responses of two cotton (Gossypium hirsutum L.) cultivars differing in resistance to leaf curl virus disease to nitrogen nutrition. Pakistan Journal of Botany 42(3):2085-2094.

70. Khan AI, Hussain M, Rauf S, Khan TM (2007). Inheritance of resistance to cotton leaf curl virus in cotton (Gossypium hirsutum L.). Plant Protection Science 43(1):5-9

71. Akhtar KP, Khan AI, Hussain M, Khan MSI (2002). Comparison of resistance level to Cotton leaf curl virus (CLCuV) among newly developed cotton mutants and commercial cultivars. Plant Pathology Journal 18(4):179-186.

72. Mahmood Z (2004). Inheritance of cotton leaf curl virus resistance in cotton (Gossypium hirsutum L.). Journal of Research (Science) 15(3):297-299.

73. Akhtar KP, Khan AI, Khan MSI (2001). Response of some cotton varieties to leaf curl virus through grafting. Pakistan Journal of Phytopathology 18:179-186.

74. Shah H, Khalid S, Hameed S (1999). Response of cotton germplasm to Cotton leaf curl virus. Proceedings. ICAC-CCRI. Regional consultation on insecticide resistance management in cotton. Multan, Pakistan. June 28 to July 1, 1999. pp. 250-256. 